Kumawula, Vol. 4, No.1, April 2021, Hal 131 - 136

DOI: https://doi.org/10.24198/kumawula.v4i1.32484

ISSN 2620-844X (online)

Tersedia online di http://jurnal.unpad.ac.id/kumawula/index

\title{
PEMBUATAN LUBANG RESAPAN BIOPORI (LRB) SEBAGAI UPAYA EDUKASI LINGKUNGAN
}

\author{
Firlawanti Lestari Baguna $^{1 *}$, Fadila Tamnge ${ }^{2}$, Mahdi Tamrin ${ }^{3}$ \\ ${ }^{1}$ Program Studi Kehutanan, Fakultas Pertanian Universitas Khairun \\ ${ }^{2}$ Program Studi Kehutanan, Fakultas Pertanian Universitas Khairun \\ ${ }^{3}$ Program Studi Kehutanan, Fakultas Pertanian Universitas Khairun \\ "Korespondensi : firlalestari@gmail.com
}

\begin{abstract}
The amount of newly built-up areas that have caused land conversion is higher. Which leads to green open spaces being reduced in number. So that the areas that can absorb water have been reduced. This program aims to increase public understanding of biopores and the positive impacts of utilizing infiltration water and organic waste for the environment. Environmental problems in Sasa include the lack of clean water availability and knowledge of organic waste management. The activities carried out were socialization and training on making biopores and organic fertilizers. The results of the activities are the installation of 10 biopore infiltrations as examples to be utilized and developed by the community, as well as the availability of solid organic fertilizers from organic waste which can be used as production inputs on agricultural land to reduce production costs and the availability of water.
\end{abstract}

Keywords: Environmental Education; Biopore, Organic garbage

\begin{abstract}
ABSTRAK
Semakin banyak lahan terbangun maka tingkat alih fungsi lahan semakin tinggi dan ruang terbuka hijau (RTH) menjadi semakin berkurang sehingga ruang resapan menjadi rendah. Program ini bertujuan untuk mengedukasi serta meningkatkan pemahaman masyarakat terhadap lubang resapan air tanah dan pemanfaatan air resapan dan sampah organik bagi lingkungan. Permasalahan lingkungan yang dihadapi Kelurahan Sasa yaitu rendahnya ketersediaan air bersih dan pengetahuan pengelolaan sampah organik. Kegiatan yang dilakukan berupa sosialisasi dan pelatihan pembuatan LRB. Hasil kegiatan yaitu terpasangnya 10 lubang resapan biopori sebagai contoh untuk dimanfaatkan dan dikembangkan oleh masyarakat, juga tersedianya pupuk organik padat dari sampah-sampah organik yang dapat digunakan sebagai input produksi pada lahan pertanian sehingga dapat mengurangi biaya produksi serta masyarakat dapat menjaga lingkungan dan ketersediaan air bersih.
\end{abstract}

Kata Kunci: Edukasi Lingkungan; Biopori; Sampah Organik

\section{PENDAHULUAN}

Permasalahan lingkungan terus berkembang dan semakin kompleks. Kepadatan penduduk dan kebutuhan umum akan berpengaruh terhadap tingkat pembangunan suatu wilayah. Semakin banyak lahan terbangun maka tingkat alih fungsi lahan akan semakin tinggi dan RTH (ruang terbuka hijau) menjadi semakin berkurang sehingga meyebabkan ruang resapan semakin sedikit. Permukiman masyarakat mulai dibangun hingga ke kaki Gunung Gamalama dan aktivitas lainnya sehingga membuka lahan yang awalnya berhutan menjadi kawasan termodifikasi. Dampak dari hal ini adalah bencana banjir pada musim hujan dan kekeringan pada musim kemarau. Elsie et al., (2017), menambahkan bahwa tidak adanya resapan air di pekarangan rumah akan memperbesar potensi terjadinya 
banjir di wilayah perkotaan.

Perubahan tutupan lahan berdampak pada zona penyerapan air hujan secara alami, sehingga air hujan yang seharusnya meresap ke tanah akan berubah menjadi air limpasan (Indriatmoko \& Rahardjo, 2015). Peraturan Menteri Negara Lingkungan Hidup Nomor 12 Tahun 2009 Tentang Pemanfaatan Air Hujan pasal 3 menyebutkan bahwa setiap penanggungjawab bangunan wajib melakukan pemanfaatan air hujan. Pemanfaatan air hujan dapat dilakukan dengan membuat biopori. Biopori merupakan lubang di dalam tanah yang terbentuk akibat berbagai aktivitas organisme di dalamnya seperti cacing, perakaran tanaman, rayap, dan fauna tanah lainnya (Peraturan Menteri Kehutanan, 2008 Nomor P.70/MenhutII/2008 Tentang Pedoman Teknis Rehabilitasi Hutan dan Lahan). Lubang-lubang yang terbentuk akan terisi udara dan akan menjadi tempat berlalunya air di dalam tanah.

Kelurahan Sasa merupakan salah satu kelurahan yang padat penduduk dan terletak pada ketinggian 0 - $45 \mathrm{~m}$ dpl (RPI2JM Kota Ternate, 2014). Krisis air bersih sering menjadi masalah yang dihadapi oleh masyarakat. Kebutuhan air bersih sering menjadi masalah pada masyarakat yang tinggal di dataran tinggi. Perubahan tutupan lahan di dataran tinggi akan berpengaruh pada ketersediaan air tanah dan banjir di daerah dataran rendah. Oleh karena itu, perlu adanya sosialisasi edukasi lingkungan melalui pembuatan biopori. Masalah lainnya yaitu sampah rumah tangga yang dibiarkan menumpuk kemudian dibakar.

Kegiatan ini akan menghasilkan karbonmonoksida $\left(\mathrm{CO}_{2}\right)$, jika terhirup manusia dapat menganggu fungsi kerja hemoglobin yang berfungsi mengangkut dan mengedarkan oksigen $\left(\mathrm{O}_{2}\right)$ ke seluruh tubuh. Rendahnya kesadaran masyarakat dalam mengelola sampah dapat menimbulkan permasalahan serius bagi lingkungan (Muchtaridi, et al. 2019)

Kegiatan Pengabdian Kepada Masyarakat (PKM) berupaya untuk memberikan edukasi kepada masyarakat mengenai manfaat biopori dan pengelolaan sampah organik. Pengelolaan sampah organik dengan biopori dapat meningkatkan nilai ekonomi sampah serta menekan biaya produksi usaha tani ataupun biaya pemeliharaan tanaman pekarangan. Selaras dengan pendapat Endyana (2019) bahwa produk-produk inovatif dari sampah sebagai salah satu strategi peningkatan kualitas lingkungan hidup dapat menguatkan sektor ekonomi kreatif.

\section{METODE}

Adapun permasalahan-permasalahan yang diidentifikasi yaitu rendahnya pengetahuan masyarakat terkait pemanfaatan air hujan serta pengelolaan sampah di masyarakat yang mampu meningkatkan pendapatan rumah tangga.

Pemanfaatan air hujan bertujuan untuk meningkatkan jumlah resapan air tanah, menghemat penggunaan air tanah dan mengurangi run off. Pemanfaatan air hujan dapat dilakukan menggunakan teknologi yang murah dan sederhana yaitu biopori atau Lubang Resapan Biopori. Pembuatan LRB menggunakan pipa paralon merek Rucika ukuran $40 \mathrm{~cm}$ diameter 4 inci, tutup pipa, alat bor, bor khusus tanah dan pisau.

Pengelolaan sampah dipilah menjadi sampah yang mudah membusuk (organik) dan sampah yang tidak mudah membusuk (anorganik). Sampah organik dapat dijadikan kompos dan sampah anorganik dapat didaur ulang menjadi kerajinan tangan. Adapun pengolahan sampah organik membutuhkan bahan seperti EM4, kapur/dolomit, pupuk kandang, daun/serasah kering, kulit buahbuahan, sampah sayuran, dan sisa makanan.

Kegiatan PKM dilaksanakan di Kelurahan Sasa Kecamatan Kota Ternate Selatan Kota Ternate pada Bulan Agustus 2020. Pelaksanaan PKM terdiri atas dua kegiatan yaitu :

(1) Kegiatan pendidikan/ sosialisasi/ edukasi.

Masyarakat Kelurahan Sasa diberikan sosialisasi mengenai manfaat dan dampak positif LRB bagi lingkungan. Sosialisasi disampaikan oleh Tim PKM melalui infografis yang disebarkan kepada Masyarakat Sasa, 
kemudian dilanjutkan dengan sesi diskusi.

(2) Kegiatan pelatihan dan pendampingan pembuatan LRB.

Kegiatan ini dilakukan bersama-sama antara mahasiswa PKM dan masyarakat Kelurahan Sasa. Jumlah LRB yang ditanam adalah 10 lubang sebagai contoh untuk dimanfaatkan dan dapat dikembangkan oleh masyarakat Kelurahan Sasa. Sebelum melakukan kegiatan sosialisasi/edukasi pendidikan dan pelatihan pembuatan LRB, masyarakat Kelurahan Sasa terlebih dahulu mengisi kuesioner. Kuesioner tersebut bertujuan untuk mengetahui tingkat pemahaman masyarakat Sasa tentang LRB, sadar sampah, dan pupuk organik.

\section{HASIL DAN PEMBAHASAN}

Hasil dan pembahasan dari kegiatan kegiatan Pengabdian Kepada Masyarakat yang telah dilakukan dapat diuraikan sebagai berikut;

\section{a. Edukasi dan Sosialisasi Lubang} Resapan Biopori

Kegiatan edukasi dan sosialisasi mengenai isu-isu permasalahan lingkungan dan potensi pemanfaatan LRB disampaikan oleh Tim PKM kepada masyarakat Kelurahan Sasa (Gambar 1a). Lubang resapan biopori diharapkan dapat memberikan manfaat ekologi dan ekonomi bagi masyarakat Sasa. Manfaat LRB secara ekologi yaitu dapat mencegah banjir, sebagai tempat pembuangan sampah organik, menyuburkan tanaman, dan meningkatkan kualitas air tanah (Sanitya \& Burhanudin, 2013; Sutandi et al., 2013), sedangkan manfaat ekonomi LRB adalah untuk efektivitas penggunaan lahan untuk menanam sampah organik, selanjutnya pupuk organik padat yang dihasilkan dapat digunakan sebagai input produksi pada lahan pertanian sehingga dapat mengurangi biaya produksi petani (Yohana et al., 2017).
Kegiatan edukasi/sosialisasi terdiri atas sesi pemaparan materi dan diskusi. Materi tentang LRB disampaikan oleh Tim PKM kepada masyarakat kemudian dilanjutkan dengan sesi diskusi. Sesi diskusi bertujuan untuk menggali informasi lebih lanjut dan memperdalam pemahaman masyarakat tentang biopori apabila dikelola dengan baik. Masyarakat Kelurahan Sasa sangat antusias mengikuti kegiatan ini terlihat dari respon positif dan begitu aktifnya masyarakat yang memberikan pertanyaan tentang LRB ini. Kegiatan ini dihadiri oleh Masyarakat Kelurahan Sasa sebanyak 30 orang yang terdiri atas 20 perempuan dan 10 laki-laki. Beberapa peserta yang terlibat dalam kegiatan ini merupakan bagian dari Kelompok Tani Kompi Grup dan Kelompok Tani Gurabula (Gambar 1b).

\section{b. Pelatihan dan Pendampingan}
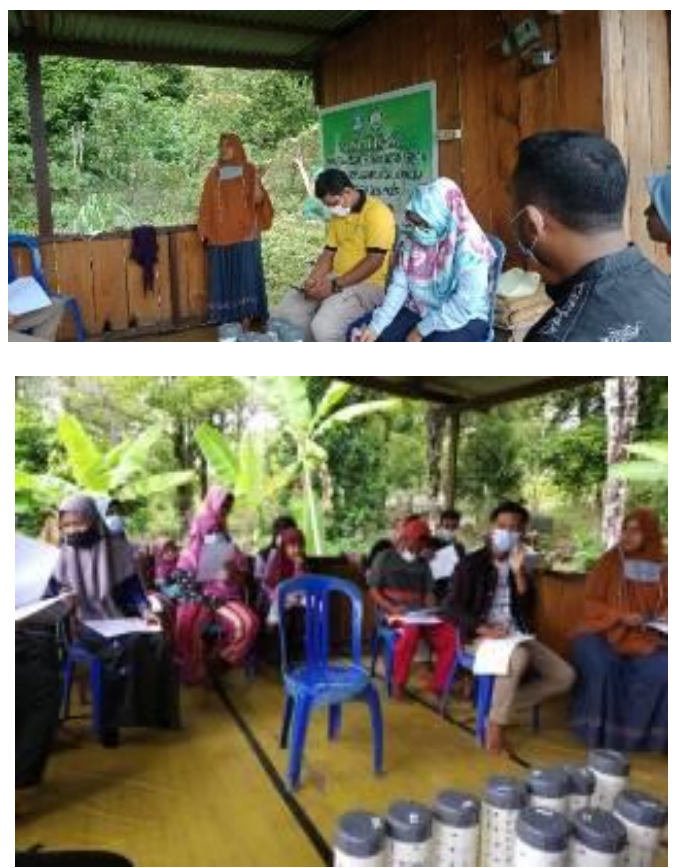

Gambar 1. Sosialisasi Pembuatan Lubang Resapan Biopori. (a) Tim memberikan pemaparan materi tentang $\mathrm{LRB}$, (b)

Suasana saat peserta sosialisasi sedang mengisi kuesioner.

Sumber: Dok Pribadi, 2020

\section{Pembuatan LRB}

Pelatihan atau training merupakan suatu kegiatan yang bermaksud untuk memperbaiki dan mengembangkan sikap, 
tingkah laku, keterampilan dan pengetahuan seseorang, sedangkan pendampingan merupakan suatu aktivitas yang dilakukan dan dapat bermakna pembinaan, pengajaran, pengarahan dalam kelompok yang lebih berkonotasi pada menguasai, mengendalikan dan mengontrol. Oleh karena itu, Pelatihan dan Pendampingan Pembuatan LRB adalah kegiatan pembinaan untuk mengembangkan pengetahuan masyarakat tentang manfaat LRB.

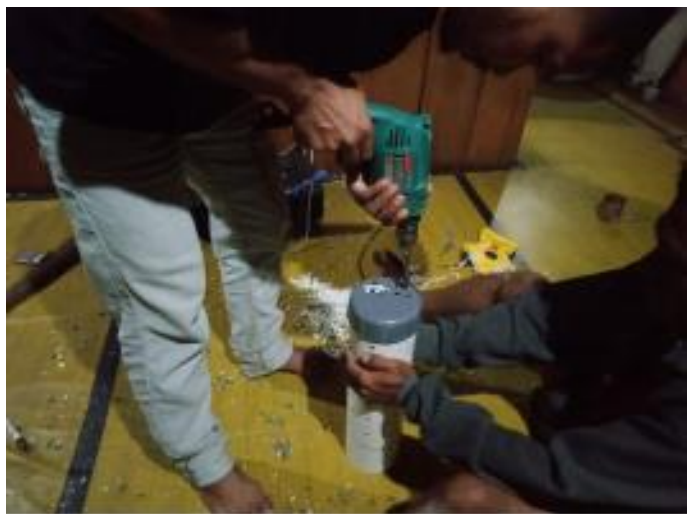

Gambar 2. Proses pembuatan alat LRB

Sumber: Dok Pribadi, 2020

Tim pengabdian melakukan pelatihan dan pendampingan pembuatan LRB kepada 30 peserta yang berasal dari Kelurahan Sasa (Gambar 2). Kegiatan ini merupakan langkah besar untuk mewujudkan konservasi air tanah melalui pembuatan LRB. Menurut Sanitya \& Burhanudin (2013), peresapan air ke dalam tanah memerlukan pemanfaatan LRB sebagai media konservasi air tanah. Konservasi air tanah merupakan upaya pelestarian air tanah dan penanganan genangan air. Hasil dari kegiatan ini yaitu terpasangnya 10 lubang resapan biopori di Kelurahan Sasa (Gambar 3). Sejumlah LRB ini dipasang di setiap titik yang dicurigai merupakan daerah genangan, daerah limpasan air hujan dari saluran pembuangan, sekeliling pohon dan pekarangan.

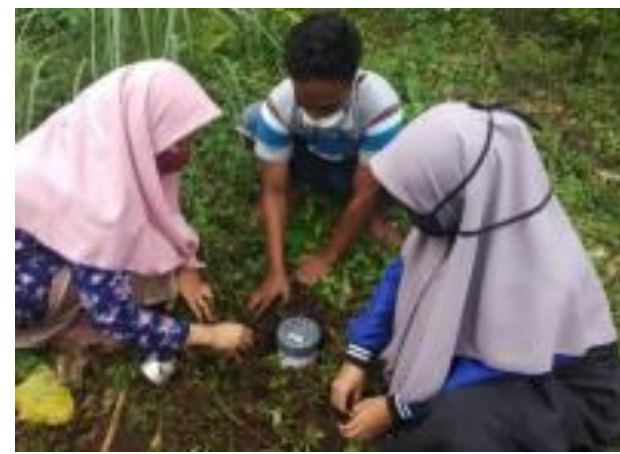

\section{Gambar 3. Penanaman Lubang Resapan Biopori}

Sumber: Doc Pribadi, 2020

Tim PKM bersama dengan mahasiswa dan masyarakat Kelurahan Sasa memasang LRB pada lubang-lubang yang telah digali sebelumnya. Lubang yang dibuat yaitu sedalam $40 \mathrm{~cm}$ dengan diameter 4 inci. Pipa Lubang Resapan Biopori (LBR) diisi dengan daun kering, ranting pohon, dan sampah sisa makanan selanjutnya ditutup menggunakan penutup pipa yang telah dilubangi. Sampah di dalam lubang akan menyusut sehingga perlu diisi kembali dan di akhir musim kemarau dapat dikuras sebagai pupuk kompos alami.

Harapan dari Tim PKM, pupuk kompos yang terbentuk dalam lubang resapan dapat dimanfaatkan oleh masyarakat Kelurahan Sasa untuk menyuburkan tanaman di halaman rumah mereka. Selama kegiatan pelatihan dan pendampingan berlangsung, masyarakat kelurahan Sasa sangat antusias karena kegiatan pelatihan LRB ini dapat membantu mereka menghasilkan pupuk kompos alami sehingga kegiatan bercocok tanaman di masa pandemi Covid-19 menjadi lebih mudah.

Menurut Sekarningrum et al (2020), partisipasi masyarakat dalam pengelolaan sampah tidak hanya tergantung pada motivasi dan sikap positif tetapi juga pada penyediaan fasilitas pengelolaan sampah yang memadai. Tim PKM menyarankan agar masyarakat Sasa bisa memodifikasi alat LBR yaitu dengan mengganti pipa dengan botol plastik berbagai ukuran 
sebagai alat LRB sehingga bisa dipasang di halaman rumah tanpa mengeluarkan biaya besar. Berdasarkan serangkaian kegiatan PKM yang telah dilakukan, diperoleh hasil bahwa ada peningkatan pengetahuan dan keterampilan mitra dalam hal ini yaitu penggunaan biopori untuk konservasi air tanah dan sadar lingkungan (Gambar 4).

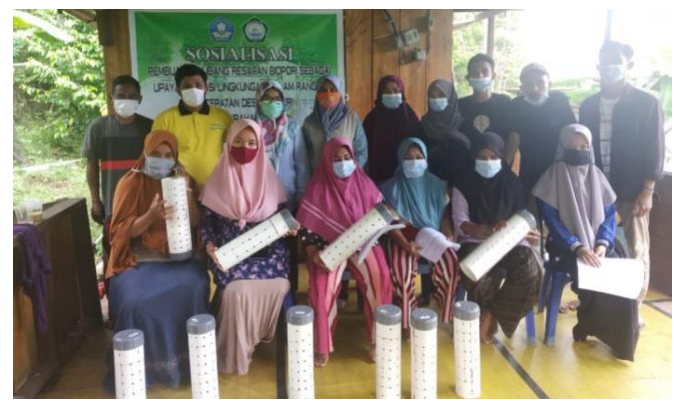

Gambar 4. Tim PKM foto bersama dengan mitra

Sumber: Dok Pribadi, 2020

\section{c. Pemanfaatan Sampah Organik}

Masyarakat Kelurahan Sasa sangat antusias dalam pendampingan pembuatan pupuk organik (kompos) sebagai pupuk ramah lingkungan yang akan digunakan oleh kelompok tani (Gambar 5). Manfaat pembuatan kompos adalah untuk meningkatkan kesuburan tanah sehingga dapat meningkatkan produksi tanaman dan dapat menekan biaya produksi secara tidak langsung.

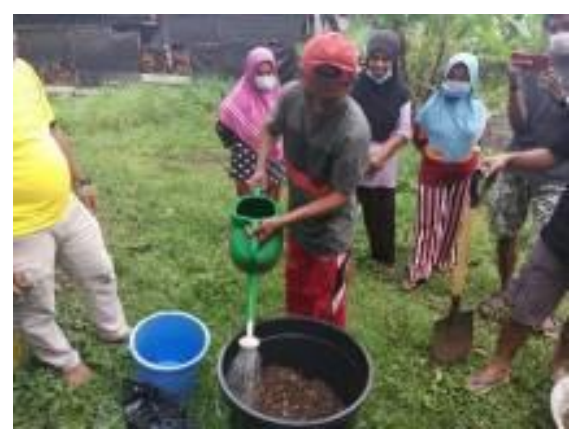

Gambar 5. Pembuatan pupuk organik bersama mitra

Sumber: Dok Pribadi, 2020

\section{d. Monitoring dan Evaluasi}

Hasil pelaksanaan kegiatan pengabdian berdasarkan hasil pre-test dan post-test yang pada berbagai tahapan edukasi lingkungan terkait pembuatan biopori. Hasil pre-test tercatat $100 \%$ peserta yang mengikuti tes belum memahami LBR. Kegiatan sosialisasi tentang LBR berjalan lancar dan memberikan sumbangsih serta manfaat positif bagi masyarakat dengan tujuan menanamkan pemahaman kepada masyarakat untuk melestarikan lingkungan, salah satunya dengan pembuatan LRB. Hasil pre-test juga menunjukkan bahwa rata-rata umur masyarakat yang mengikuti kegiatan sosialisasi adalah 23 tahun yang terdapat pada kisaran kelompok $19-40$ tahun. Usia menunjukkan bahwa peserta sosialisasi masih memiliki kemampuan untuk menerima pengetahuan atau informasi baru untuk memperbaiki lingkungannya melalui pembuatan LRB.

Setelah tahapan sosialisasi dan pelatihan pembuatan biopori serta pendampingan pembuatan sampah. Peserta kembali diberikan kuesioner untuk mengukur pengetahuan peserta terkait ruang lingkup serta manfaat dari LBR. Hasil post-test menunjukkan bahwa 100\% peserta dapat memahami ruang lingkup dan manfaat LBR, pemanfaatan air hujan, serta pengelolaan sampah. Hasil monitoring menunjukkan bahwa LBR bermanfaat dalam penyerapan air hujan ditandai dengan tidak ada genangan air serta terurainya sampah yang dimasukkan ke dalam lubang. Serta terdekomposisinya pupuk organik dari pemanfaatan sampah organik.

\section{SIMPULAN}

Simpulan berdasarkan hasil-hasil yang diperoleh dari kegiatan PKM, kelebihan dan kekurangan serta kemungkinan pengembangan selanjutnya, dapat disimpulkan bahwa telah terapasangnya 10 Lubang Resapan Biopori di 10 titik lokasi, dan meningkatnya pengetahuan masyarakat mengenai manfaat LRB secara ekonomi dan lingkungan serta dapat mengurangi masalah sampah organik dan biaya 
produksi dalam usaha tani. Pembuatan LRB masih perlu digalakkan di Kota Ternate. Seluruh elemen masyarakat dan sivitas akademika harus mendukung pelaksanaan program LRB sebagai bentuk rasa peduli terhadap lingkungan.

\section{UCAPAN TERIMA KASIH}

Kami ucapkan Terima kasih kepada pihak LPPM Universitas Khairun yang telah memberikan bantuan dana Pengabdian kepada Masyarakat (PKM) Tahun Anggaran 2020. Mahasiswa dan Alumni Program Studi Kehutanan Universitas Khairun yang telah membantu persiapan kegiatan ini: Munajad Dj. Achmad, M. Fatwa Sahril, Reza Hasrullah, M. Noviar, dan Susadri Sarifudin.

\section{DAFTAR PUSTAKA}

Endyana, C. 2019. Peningkatan Kualitas Lingkungan Hidup dengan Pengembangan Ekonomi Kreatif Warga Desa Cileunyi Wetan Kabupaten Bandung. Jurnal Kumawula, 2(3) : $201-$ 210.

(http://jurnal.unpad.ac.id/kumawula/arti cle/view/24551/pdf)

Elsie, E., Harahap, I., Herlina, N., Badrun, Y., \& Gesriantuti, N. (2017). Pembuatan Lubang Resapan Biopori Sebagai Alternatif Penanggulangan Banjir Di Kelurahan Maharatu Kecamatan Marpoyan Damai Pekanbaru. Jurnal Pengabdian UntukMu NegeRI, 1(2), 9397.

(https://doi.org/10.37859/jpumri.v1i2.24 2)

Indriatmoko, H., \& Rahardjo, N. (2015). Kajian Pendahuluan Sistem Pemanfaatan Air Hujan. JAI, 8(1), 105-114.

Menteri Negara Lingkungan Hidup. (2019). Peraturan Menteri Negara Lingkungan Hidup Nomor 12 Tahun 2019 Tentang Pemanfaatan Air Hujan.

Muchtaridi, Suhandi C, Gwiharto AK. 2019. Sosialisasi Pengolahan Sampah di Desa Sukarapih sebagai Upaya Preventif Pencemaran Sungai Citarum. Jurnal Kumawula, 2(3) : 326-235. (http//jurnal.unpad.ac.id/kumawula/inde
X)

Peraturan Menteri Kehutanan. (2008). Peraturan Menteri Kehutanan Nomor: P.70/Menhut-II/2008 Tentang Pedoman Teknis Rehabilitasi Hutan dan Lahan. (https://docplayer.info/33555919-

Peraturan-menteri-kehutanan-nomor-p70-menhut-ii-2008-tentang-pedomanteknis-rehabilitasi-hutan-danlahan.html).

RPI2JM Kota Ternate. (2014). Profil kota Ternate.

Sanitya, R., \& Burhanudin, H. (2013). Penentuan Lokasi dan Jumlah Lubang Resapan Biopori Di Kawasan Das Cikapundung Bagian Tengah. Jurnal Perencanaan Wilayah Dan Kota, 13(1), 124504.

Sekarningrum, B., Suprayogi, Y., \& Yunita, D. 2020. Penerapan Model Pengelolaan Sampah "Podjok Kangpisman" . Jurnal Kumawula, 3(3) : 548 - 560. (http://jurnal.unpad.ac.id/kumawula/artic le/view/29740/pdf)

Sutandi, M. C., Husada, G., Tjandrapuspa, K., Rahmat, D., \& SSoSanto, T. (2013). Penggunaan Lubang Resapan Biopori untuk Minimalisasi Dampak Bahaya Banjir pada Kecamatan Sujajadi Kelurahan Sukawarna RW004 Bandung. Konferensi Nasional Teknik Sipil 7 (KoNTekS 7), 978-979.

Yohana, C., Griandini, D., \& Muzambeq, S. (2017). Penerapan Pembuatan Teknik Lubang Biopori Resapan Sebagai Upaya Pengendalian Banjir. Jurnal Pemberdayaan Masyarakat Madani (JPMM), 1(2), 296-308. https://doi.org/10.21009/jpmm.001.2.10 